\title{
Managing the carbon rift: Social metabolism, geoengineering and climate capitalism $^{1}$
}

[Paper presented at the American Sociological Association meeting, Seattle, Aug 20-24, 2016]

Jean Philippe Sapinski

Department of Sociology

University of Oregon

sapinski [at] uvic.ca

\begin{abstract}
The idea that climate geoengineering could be used in conjunction to reducing greenhouse gas emissions to avoid catastrophic climate change has gained credence in both scientific and policy circles. Because of the inherent uncertainty about the risks involved, debates on the topic abound. Scientists agree that more research is needed on both the potential impacts of geoengineering on humans and ecosystems, and the governance mechanisms that would be the most appropriate for conducting field research and for eventual deployment. Despite an explosion of publications in the last decade or so, properly sociological analysis is still lacking. In this paper, we develop an approach to geoengineering based on metabolic rift theory to consider the broad political economic context in which geoengineering technologies are being developed. We argue first that the eventual recourse to such last resort approaches is a consequence of the ever expanding carbon rift created by capitalism and the growth imperative it entails. Second, we discuss how geoengineering technologies would likely be deployed within the context of the neoliberal climate policy regime that is currently in place and that relies heavily on carbon markets. We outline some of the foreseeable consequences of tying geoengineering to carbon markets on greenhouse gas emissions reduction and on the possibility of exerting democratic control over the technologies themselves.
\end{abstract}

\section{Introduction}

The idea that climate geoengineering - the large scale intentional modification of the climate system could provide a way to counteract the global warming effect of greenhouse gases has been circulating since at least the 1960s (Foster 2015; Schneider 2001). However, it is only during the last decade that it has moved from the margin to the center of climate policy debates. The idea has also made its way into policy circles with the publication of several high profile reports (Edenhofer et al. 2011; National Research Council 2015a, 2015b; Rickels et al. 2011; The Royal Society 2009). More recently, it has become clear that climate change projection scenarios assume some form of geoengineering 'negative emission technologies' - to avoid catastrophic climate disruption (Fuss et al. 2014; Smith et al. 2016). Reliance on such negative emissions technologies has now been embedded politically in the December 2015 Paris Agreement (Anderson 2015). This contentious topic is attracting a great deal of debate among scholars and commentators. However, beyond limited political science and law scholarship dedicated to elaborating governance frameworks (Burns 2011, 2013; Michaelson 1998;

1 Thanks to Holly Jean Buck and Nils Markusson for their comments on an earlier draft of this paper. This work is supported by a post-doctoral fellowship from the Social Sciences and Humanities Research Council of Canada. 
Parson 2014; Parson and Ernst 2015), social sciences - and especially sociology - have been greatly underrepresented in these discussions (although see Asayama 2015; Buck 2012, 2013). As well, critical political economic analysis is currently just emerging (see Malm 2015; Surprise 2015).

This paper contributes to furthering sociological and political economic understanding of geoengineering in the context of the neoliberal regime of accumulation and the capitalist mode of production more broadly. I start by reviewing current debates around experimental field research of geoengineering technologies, their eventual governance and deployment. Then I examine how such technologies would insert themselves within the metabolic relationship between humans and the territories they inhabit, and the effects they would have on the ever expanding rift in the carbon cycle. In the last two sections, I develop a critical understanding of geoengineering as located within the hegemonic neoliberal discourse of 'earth system management', and delineate how such interventions would come into play within the currently existing political economy of climate change revolving around carbon markets and perhaps carbon taxes.

\section{Current debates around geoengineering}

Geoengineering is defined as 'the deliberate large-scale intervention in the Earth's climate system' (The Royal Society 2009:ix). The term is used as an umbrella concept that covers multiple techniques that either remove carbon dioxide $\left(\mathrm{CO}_{2}\right)$ from the atmosphere - referred to as 'carbon dioxide removal' (CDR) or reduce the amount of solar radiation that hits the earth's surface - 'solar radiation management' (SRM). Examples of CDR technologies include running machines that remove $\mathrm{CO}_{2}$ from the air and spreading large quantities of iron dust into the ocean so as to increase production of $\mathrm{CO}_{2-}$ absorbing algae. Capture of $\mathrm{CO}_{2}$ emissions from wood and grass burning power plants was the most discussed negative emissions technology at the Paris COP 21, and also enters into this category. Because the quantities of $\mathrm{CO}_{2}$ that can be removed from the atmosphere are small in comparison to the quantities already present, such interventions work on a long time frame and thus are considered having the same effect on $\mathrm{CO}_{2}$ concentrations as directly reducing $\mathrm{CO}_{2}$ emissions. For their part, SRM strategies seek to modify the heat trapping potential of the high atmosphere, either by reflect sunlight back into space by spreading sulfur particles or engineered nanoparticles into the stratosphere referred to as 'stratospheric aerosol injection', by spraying water vapor from the oceans to make oceanic clouds brighter and thus more reflective, or by seeding and dispersing heat-trapping cirrus clouds. Because of its relatively low cost, ease of deployment and rapid effect on global temperature, stratospheric aerosol injection is the option that is the most seriously considered as a complement to reducing greenhouse gas (GHG) emissions.

Beyond technical feasibility studies and economic cost-benefit analyses, debates around geoengineering, and particularly stratospheric aerosol injection, pertain to whether field experiments should be allowed to proceed and if so, how such research should be governed. A handful of climate scientists and advocacy organizations warn of the great potential for dangerous and unpredictable effects on human societies at the global and local levels (e.g., Barrett et al. 2014; Cusack et al. 2014; ETC Group 2010; Robock 2008, 2012; Schneider 1996; Sillmann et al. 2015). Climate scientists overwhelmingly agree that all geoengineering technologies carry considerable unknown risks and that 
they must not be considered an alternative to reducing GHG emissions. Nonetheless, most believe that research should move forward to better understand the cooling potential, specific effects and risks involved, in the eventuality that GHG emissions would not be reduced rapidly enough to avoid catastrophic climate change. To that effect, a small number of climate scientists and law scholars have been advocating the pursuit of broad research programs on the various geoengineering technologies (e.g., Crutzen 2006; Keith 2013; Keith et al. 2010; Parson and Ernst 2015; Schneider 2001). Given the mismatch between the targets agreed upon in the Paris Agreement and each country's voluntary emissions commitments and the level of warming locked-in from past emissions, some scholars are advocating using SRM in parallel to reducing GHG emissions (Burns 2015; Keith and MacMartin 2015; Parson 2014). Thus, current discussions revolve around developing governance mechanisms which would allow field experimental research - extremely contested up to now (see Marshall 2011; Shiermeier 2009) - to proceed under legitimate arrangements, and provide a basic framework for eventual deployment (Parson and Ernst 2015).

As geoengineering proposals were becoming more credible in the last few years, critical literature from social sciences and humanities scholars developed as well. The majority of the humanities scholarship takes a discourse analytic approach to critically deconstruct the scientific geoengineering discourse. Hulme (2014) provides the most elaborate such attempt to date. He outlines the discourse of 'climate emergency' that underpins all discussions of geoengineering and the argument that a 'Plan B' for regulating the climate is necessary, as well as the framing of technology as all powerful in such discourses. He also analyses the multiple metaphors of management that treat the earth as an object external to humanity and that can be managed as such. By doing so he asks the question of the agencies underpinning this discourse and thus directs attention to some of the relationships of power behind it (see also Cairns and Stirling 2014). Luke (2010) lays out a similar argument and warns about the effects of such technologies on social relations and the new relationships of domination and the rule of experts they foster. Other scholars have looked at public opinion and media portrayal. Buck (2013) found that in 2010, a small group of people framed the topic in the UK media. More recent studies of English-language print media find a decline in deterministic frames and a greater proportion of frames addressing sociopolitical questions (Scholte et al. 2013), as well as a greater proportion of articles critical of geoengineering (Anshelm and Hansson 2015). Harnisch et al. (2015) find important differences between discourse in the US, the UK and Germany, as for example the narrative in the US portrays SRM technologies as very circumscribed interventions with predictable effects whereas in Germany scientists emphasize risk and urge caution. Finally, some studies have looked at public engagement with the topic through qualitative interviews. They insist on the difficulties of engaging the public given the lack of general knowledge about the issue (Corner et al. 2012), and emphasize the role of social sciences in fostering democratic public engagement in debates (Macnaghten and Szerszynski 2013).

The little critical political economic analysis that exists describes geoengineering as a 'technological fix' or a 'spatio-temporal fix' that displaces the cost of the problem to other geographical locations and to future generations, and dismiss it as too risky to be undertaken and as not addressing the root of the problem - the capitalist mode of production and the growth imperative it entails (Klein 2014:Chap. 8; 
Malm 2015). It is only very recently that political economic analysis engaged more thoroughly with the topic to develop an understanding of geoengineering within the context of capitalism and the neoliberal regime. Malm (2015) draws on Harvey (1999) to develop the argument that in a fossil fuel-based capitalist economy, geoengineering allows fossil fuel corporations to fully recover the capital investments they made in extraction, refining and distribution infrastructure. Further theorizing geoengineering from a materialist perspective, Surprise (2015) asks 'how capital, capitalist nationstates, and techno-managerial elites might coordinate a geoengineering regime to manage the now planetary-scale contradictions of capitalism' and considers how geoengineering might enable a total control of production through coordinated, techno-scientific management - what Smith (2007) describes as the 'real subsumption' of biosphere under capital.

The rest of this paper builds on this emergent trend. It approaches geoengineering from the perspective of metabolic rift theory so as to consider the political ecological and political economic context in which such technologies are discussed and might be utilized. First, in terms of political ecology, it will reframe geoengineering technologies within the context of the metabolic relationship between humans and the territories they inhabit, and the growing carbon rift they purport to address (see Clark and York 2005). Second, it will consider how geoengineering would insert itself within the political economy of climate change founded on neoliberal market instruments such as carbon markets and carbon taxes (see Lohmann 2014). It will consider geoengineering as an integral part of the capitalist mode of production and of the emergent climate capitalist regime developed to address the threat to accumulation posed by climate change while avoiding major changes in political-economic structures.

\section{Social metabolism, the carbon rift and geoengineering}

The relationship between humans and the environment they live in can be described as a social metabolism. This is simply a way to designate the circulation of matter and energy that takes place between a human society and the environment it is embedded in, and within that society considered as a bounded entity. Thus, humans expend energy in the form of labor to appropriate, transform and redistribute certain materials from their environment, which serve to maintain the internal organization of the societies of which they are part, and in turn to maintain themselves (Foster 1999). This metabolic relationship takes place within pre-existing natural constraints, and in turn affects nature in multiple and novel ways (Foster et al. 2010:124). This metabolic process encompasses every exchange between human societies and the environment of which they are a part, such as growing food in gardens, animal hunting, ore and petroleum extraction, composting, or greenhouse gas emissions. The concept of social metabolism asserts that this exchange of matter and energy is a social process, which furthermore comprises two interrelated aspects. On the one hand, social metabolism involves economic relations, as human labor appropriates and transforms matter and energy, and distributes the use values thus created among the group. On the other hand, this labor is performed as a group, and the distribution of use values is determined by political relations within the group, that is, the institutions its members have created and the power struggles taking place among them. Hence, the economic process of the circulation of matter and energy between a society and its environment is socially regulated by means of political mechanisms and institutions. 
As human societies are an integral part of their environment, their social metabolism insert themselves within natural cycles and transform them to various extents. During the last few centuries, the emergence of capitalism as a mode of organizing and regulating production has affected many natural cycles in critical ways (e.g. Longo et al. 2015; Magdoff and Foster 2011; Rockström et al. 2009; Schultz and York 2011; Smith et al. 2014). Observing some of the consequences of the industrial revolution during the $19^{\text {th }}$ century, Marx discussed how the increased scale of capitalist agriculture created a metabolic rift, as soils were depleted by removing nutrients from the countryside and moving them to cities, and eventually the rivers that run through them. This rift was managed by importing guano to keep up soil fertility, and later by adding artificial fertilizers as guano deposits were being exhausted (Foster 1999, 2000). A similar rift in the carbon cycle has been expanding since fossil fuels have started being extracted from the ground and burned, and the resulting carbon dioxide released in the atmosphere (Clark and York 2005). Thus, in general, a metabolic rift is created when human groups extract matter from one place, affecting that place - potentially irreversibly, use up (i.e. 'metabolize') the matter extracted to create use values for their needs and desires, and eventually reject that matter or part of it in another place where it has detrimental effects, in the form of waste and pollution.

Metabolic rifts have existed throughout human history. However, capitalism - the dominant way in which humans currently relate to and organize nature - creates and expands rifts systematically, as part of its normal operation. Because of competitive pressures driving capitalism, metabolic rifts keep expanding. For example, capitalist agriculture intensifies production by means of mechanization, which pushes greater numbers of people off the land and into cities, in turn increasing the rift. Capitalist farmers need to employ technological means to circumvent the rift, such as petroleum-based fertilizers and pesticides, and further mechanization - which all in turn create or exacerbate rifts elsewhere as they contribute to climate change, destroy insect and plant populations, and produce nitrogen-rich runoff waters which create dead zones in the oceans. Hence, these technologies, far from mending the metabolic rift, simply create problems elsewhere.

Geoengineering technologies purport to address the carbon rift in similar ways ${ }^{2}$, although most of their effects on populations are currently under-documented. Carbon dioxide removal technologies such as large scale tree plantations or so-called 'artificial trees' create major problems because of the sheer amount of land required to implement them on the scale necessary to address the problem. First, their effect on biogeochemical cycles, and thus on ecosystems, would be greater than that of historical land use change (Heck et al. 2015). Second, they would impact landholders and thus global food production, by either providing an incentive to farmers to shift food production to CDR plantations, or by displacing smallholders from their lands. The impact on the price of staple foods and/or on the capacity to produce food would be felt the greatest by the poorest, which poses an obvious social justice issue as the cost of addressing the carbon rift is displaced onto them. For their part, ocean fertilization projects are inherently based on marine ecosystem disruption (Strong et al. 2009:347) and thus put the costs on fisherfolks who depend on these ecosystems for their livelihoods. Thus, as with other neoliberal means of addressing climate change (Isla 2015; Salleh 2012), reproductive workers end up bearing the brunt

2 Thanks to Nicole Bates-Eamer for drawing our attention on the similarities between these historical processes. 
of the costs of decarbonization by geoengineering, even though they contributed very little to the problem in the first place.

Solar radiation management technologies have a different set of consequences, as they mainly affect the climatic system. Climate modelling research found that SRM entails regional disparities in the distribution of its benefits and risks (Kravitz et al 2014; Moreno-Cruz et al. 2012) and that it would have effects on precipitation patterns, fostering a drier climate overall (National Research Council 2015b). However, the greatest concern is the inherent uncertainty about the consequences of modification of the climate system, as 'a single intervention can cause multiple non-linear feedbacks to weather and climatic patterns over multiple time-scales' (Cusack et al. 2014). The main problem is that no test can be designed that would permit researchers to assess these impacts, short of full scale implementation. Moreover, even in the case of global deployment, specific variations could not be attributed to the intervention (Robock 2012). Another major concern is the possibility that SRM comes to be relied upon instead of reducing emissions, which would entail both ever increasing $\mathrm{CO}_{2}$ atmospheric concentrations, with their consequences on ocean acidity and marine ecosystems, as well as on terrestrial ecosystems, in parallel with ever increasing SRM intervention (National Research Council 2015b:43). In sum, because of inherent uncertainty about the effects of SRM on the climate system, it is difficult to pinpoint how and to whom costs will be shifted if such technologies were to be used. Geoengineering researchers insist that such unknown costs need to be weighed against the well known costs of catastrophic climate change that are mostly borne by women, small landholders and peasants, fisherfolks, and indigenous people, and that thus SRM deployment would serve environmental justice purposes (Keith 2013; Parson and Ernst 2015). However, in the foreseeable case in which SRM would have for effect to postpone - perhaps indefinitely - reduction of GHG emissions, then SRM would truly serve the purpose of a temporal fix and delay the worse economic impacts of climate change and transfer them onto future generations.

In sum, CDR and SRM technologies address the carbon rift in different ways, though both actually enable further expansion of the rift. CDR acts over the long term and displace the costs of climate change from capitalists to reproductive workers, by allowing the former to continue emitting GHGs and accumulating profits as states fund geoengineering projects that increase food prices, perhaps push subsistence farmers off their lands, and delay emissions reductions. CDR thus acts as a spatial fix; however, because of the long time frame of its effects on $\mathrm{CO}_{2}$ concentrations, it does not act as a temporal fix. On the contrary, SRM moves the impacts of climate change in time. It reduces rapidly global temperatures, thus allowing more GHGs to be emitted - actually extending the carbon budget. Unless GHG emissions are reduced concomitantly, this leaves the problem intact, displacing the costs to reduce emissions on future generations, and locking them into maintaining SRM schemes to avoid a rapid increase in temperatures - a so-called 'termination effect'. Even if emissions are reduced in parallel to SRM deployment, as Malm (2015) emphasizes, it still allows the short-term valorization of existing fossil fuel infrastructure and its replacement over a long time frame, consequently moving the costs from capitalists to those living in the regions suffering the side-effects of SRM. Hence, SRM works as both a spatial and temporal fix for the carbon rift, allowing to manage some of its consequences and to ensure that capitalist accumulation can proceed. 
The perspective of the social metabolism developed in this section emphasizes the political economic context in which technologies such as geoengineering emerge. The next section considers how climate change has been addressed in the context of the neoliberal regime, and how geoengineering technologies might be governed and deployed given the political economic relations neoliberalism entails.

\section{Climate capitalism and geoengineering}

Newell and Paterson (2010) coined the term 'climate capitalism' to describe the regime based on voluntary and state-led carbon markets that has developed into a de facto governance framework for climate politics since the signature of the Kyoto Protocol in 1997. Economically, climate capitalism mainly relies on carbon markets to reduce GHG emissions by making the endeavor profitable. In a first step, carbon markets create new commodities - permits to emit one ton of $\mathrm{CO}_{2}$ or its equivalent. Secondly, they provide an institutional structure for emitters to trade these commodities. These will be sold or bought according to whether it is more profitable for emitters to reduce their emissions or to buy extra permits to cover their emissions. This allows those firms who reduce their emissions to capture extra revenues through the sale of permits, and those who do not reduce them to avoid enacting changes in their production methods and to in effect pay others to do so (Bumpus and Liverman 2008; Lohmann 2006; Newell and Paterson 2010). Carbon markets are thus in line with neoliberal environmentalism, which has for goal to reconcile capital accumulation and environmental protection (see Bernstein 2002). Politically, the multiple actors and networks which participate in carbon market transactions have used the institutional architecture provided first by the Kyoto Protocol, and later by the different carbon markets established in different jurisdictions, to create together a decentralized governance regime. This regime has solidified over time as more and more players have joined in, and now appears to be firmly in place (Betsill and Hoffmann 2011; Paterson et al. 2014). Recently, the Paris Agreement further consolidated the position of climate capitalist climate governance by callig for the development of a global carbon market to achieve its objectives (Böhm 2015; Morgan 2016; Spash 2016).

Despite that they work as the main climate policy instrument and as the global climate governance regime, the price of emission permits on the different carbon markets have been consistently much lower than what would be required to have any economic effect, and carbon markets have up to now failed to encourage any meaningful emissions reductions (Vlachou 2014). They have however proved an effective way to support large scale energy generation projects and schemes seeking to enclose forest commons in the global South, and thus have served to redistribute wealth and land rights to capitalist elites (Böhm et al. 2012; Böhm and Dabhi 2009; Isla 2015; Lohmann 2006, 2008).

Furthermore, as a project of a section of the global corporate elite, climate capitalism constitutes a compromise regime between climate change denial and the demands for deep structural change of climate justice activists and scholars (Sapinski 2015, 2016).

Direct profit opportunities from geoengineering are rather limited, given the relatively low cost of SRM interventions and the long time frame over which CDR technologies would be deployed. They would be circumscribed to relatively small contracts and to rent from patented technologies (Buck 2012). In 
the context of the climate capitalist regime however, at least some geoengineering strategies would depend on the production of commodity carbon credits, and research to assess that possibility is already being conducted regarding BECCS (Haro et al. 2015), biochar application (Galgani et al. 2014), ocean iron fertilization (Rickels et al. 2012) and SRM (Lockley 2016; Sargoni and Lockley 2015). As discussed above, the discourse of 'innovation' that is deeply embedded within the neoliberal discourse obscures both the types of new technologies that are thought to help address climate change, and how these technologies would fit within and transform existing political economic relationships. Thus, 'low carbon' innovations comprise cheaper solar panels and windmills alongside geoengineering technologies. The existing regime of climate capitalism that now governs climate change policy delineates a very specific niche for geoengineering technologies in the accumulation process: the production of cheap carbon credits to be sold on carbon markets to offset $\mathrm{CO}_{2}$ emissions. In a competitive market, all means of producing commodity carbon credits compete together. Thus, for a similar use value - the offsetting of a ton of $\mathrm{CO}_{2}$ emitted, abstracted from any context of production the exchange value of carbon credits will be the sole determinant of how these credits will be produced.

Of course, acceptance of geoengineering produced carbon credits on carbon markets is far from given. Currently existing emissions trading schemes restrict credits according to the borders of participating jurisdictions. This means geoengineering credits could only be traded on the voluntary carbon market, by definition not subjected to such restrictions (Sargoni and Lockley 2015). Nonetheless, there are strong pressures to harmonize existing markets into a single international carbon market, and the Paris Agreement explicitly encourages such a movement (Böhm 2015). Given its scope, such a global market may not be subject to this restriction and thus might allow for the trade of carbon credits produced through geoengineering (Sargoni and Lockley 2015). Of course, geoengineering produced carbon credits could be explicitly excluded from a global market - perhaps to subject of international negotiations. As well, buyers of credits on voluntary markets may refuse to buy geoengineering credits, thus limiting the market further. Further, some studies find that the price that would be required for some geoengineering strategies to be competitive is far from the low price at which all markets are trading currently (Galgani et al. 2014; Haro et al. 2015; Rickels et al. 2012). It is hence unclear how extensive the actual market would be.

The possibility remains though that, given the current neoliberal climate governance regime, geoengineering deployment would be at least partly governed through market mechanisms. This appears unlikely in the case of SRM strategies, because of their centralized governance and relatively cheap technical requirements. However, CDR strategies would likely depend on carbon market revenues for their financial viability. This would have for consequence first, to create an economic interest for companies invested in the sector and thus lock them in this specific source of profit. Second, and more importantly, certain geoengineering strategies could produce cheaper carbon credits that would outcompete carbon credits produced through actual emissions reduction. This would have for effect to displace climate action away from actually reducing GHG emissions, and toward geoengineering. In sum, once started, it would become difficult to backtrack on the process, and geoengineering would counter the incentive to 'decarbonization', through the simple operation of the carbon market. Furthermore, given the inherently unpredictable nature of carbon markets (Lohmann 
2014), a crash in carbon prices might undermine the profitability of geoengineering schemes and thus carry a risk of abrupt termination, which would in the case of SRM strategies potentially lead to catastrophic consequences.

\section{Conclusion}

This article sought to understand how proposals for implementing geoengineering technologies to address climate change fit within the current political ecological and political economic context. First, it has used the concept of social metabolism to argue that geoengineering would not mend the carbon rift created by capitalism but rather displace the costs of addressing the problem to the reproductive working class and to future generations. The second part of the analysis has focused on the current climate capitalist political economic regime governing climate politics. It finds that the deployment of geoengineering strategies would likely take place as part of either the voluntary carbon market or an eventual globally integrated market, thus creating two sets of risks. First, because of competitive pressures to produce commodity carbon credits at the lowest cost, geoengineering technologies might displace actual emissions reductions. Second, volatility in carbon prices would affect the production of commodity carbon credits in unpredictable ways, thus compounding certain known risks of geoengineering technologies.

The critical political economic analysis developed here starkly contrasts with the majority of political science and law scholarship on geoengineering. This body of literature assumes that geoengineering will be deployed following decisions by one or a coalition of powerful governments deciding that the urgency of the climatic situation requires a 'Plan B' to be enacted. However, under the current neoliberal regime, nation-states share historic agency with a growing number of global actors. This article suggest that under existing arrangements, non-state financial actors and market forces might exert the greatest agency over the deployment of geoengineering, thus removing these technologies even further from any sort of democratic control.

\section{References}

Anderson, Kevin. 2015. “Talks in the City of Light Generate More Heat.” Nature News 528(7583):437.

Anshelm, Jonas and Anders Hansson. 2015. "Has the Grand Idea of Geoengineering as Plan B Run out of Steam?” The Anthropocene Review Forthcoming.

Asayama, Shinichiro. 2015. “Catastrophism toward ‘opening Up’ or ‘closing Down’? Going beyond the Apocalyptic Future and Geoengineering.” Current Sociology 63(1):89-93.

Barrett, Scott, Timothy M. Lenton, Antony Millner, Alessandro Tavoni, Stephen Carpenter, John M. Anderies, et al. 2014. “Climate Engineering Reconsidered.” Nature Climate Change 4(7):527_ 29.

Bernstein, Steven. 2002. The Compromise of Liberal Environmentalism. New York: Columbia University Press.

Betsill, Michele and Matthew J. Hoffmann. 2011. “The Contours of 'cap and Trade’: The Evolution of Emissions Trading Systems for Greenhouse Gases.” Review of Policy Research 28(1):83-106.

Böhm, Steffen. 2015. “How Emissions Trading at Paris Climate Talks Has Set Us up for Failure.” The Conversation. 
Böhm, Steffen and Siddhartha Dabhi, eds. 2009. Upsetting the Offset: The Political Economy of Carbon Markets. London: MayFlyBooks.

Böhm, Steffen, Maris Ceci Misoczky, and Sandra Moog. 2012. "Greening Capitalism? A Marxist Critique of Carbon Markets.” Organization Studies 33(11):1617-38.

Buck, Holly Jean. 2012. “Geoengineering: Re-Making Climate for Profit or Humanitarian Intervention?” Development and Change 43(1):253-270.

Buck, Holly Jean. 2013. “Climate Engineering: Spectacle, Tragedy or Solution? A Content Analysis of News Media Framing.” Pp. 166-80 in Interpretive Approaches to Global Climate Governance: Deconstructing the Greenhouse, edited by Chris Methmann, Delf Rothe, and Benjamin Stephan. New York: Routledge.

Bumpus, Adam G. and Diana M. Liverman. 2008. “Accumulation by Decarbonization and the Governance of Carbon Offsets.” Economic Geography 84(2):127-55.

Burns, Wil. 2013. “Introduction: Climate Change Geoengineering.” Carbon \& Climate Law Review 2013(2):87-89.

Burns, Wil. 2015. "Into the Great Wide Open? The Promise and Potential Perils of Climate Geoengineering.”

Burns, William C. G. 2011. "Climate Geoengineering: Solar Radiation Management and Its Implications for Intergenerational Equity.” Stanford Journal of Law, Science \& Policy 19 pages.

Cairns, Rose and Andy Stirling. 2014. “'Maintaining Planetary Systems’ or 'concentrating Global Power?’ High Stakes in Contending Framings of Climate Geoengineering.” Global Environmental Change 28:25-38.

Clark, Brett and Richard York. 2005. "Carbon Metabolism: Global Capitalism, Climate Change, and the Biospheric Rift.” Theory and Society 34(4):391-428.

Corner, Adam, Nick Pidgeon, and Karen Parkhill. 2012. "Perceptions of Geoengineering: Public Attitudes, Stakeholder Perspectives, and the Challenge of ‘upstream' Engagement.” Wiley Interdisciplinary Reviews: Climate Change 3(5):451-466.

Crutzen, Paul J. 2006. “Albedo Enhancement by Stratospheric Sulfur Injections: A Contribution to Resolve a Policy Dilemma?” Climatic Change 77(3-4):211-20.

Cusack, Daniela F., Jonn Axsen, Rachael Shwom, Lauren Hartzell-Nichols, Sam White, and Katherine RM Mackey. 2014. “An Interdisciplinary Assessment of Climate Engineering Strategies.” Frontiers in Ecology and the Environment 12(5):280-87.

Edenhofer, Ottmar, Ramón Pichs-Madruga, Youba Sokona, Christopher Field, Vicente Barros, Thomas F. Stocker, et al., eds. 2011. IPCC Expert Meeting on Geoengineering: Meeting Report. Potsdam: IPCC Working Group III Technical Support Unit and Potsdam Institute for Climate Impact Research.

ETC Group. 2010. Geopiracy: The Case Against Geoengineering. Ottawa: ETC Group.

Foster, John Bellamy. 1999. “Marx’s Theory of Metabolic Rift: Classical Foundation for Environmental Sociology.” American Journal of Sociology 105(2):366-405.

Foster, John Bellamy. 2000. Marx’s Ecology: Materialism and Nature. New York: Monthly Review Press.

Foster, John Bellamy. 2015. “Late Soviet Ecology and the Planetary Crisis.” Monthly Review 67(2). 
Foster, John Bellamy, Brett Clark, and Richard York. 2010. The Ecological Rift: Capitalism's War on the Planet. New York: Monthly Review Press.

Fuss, Sabine, Josep G. Canadell, Glen P. Peters, Massimo Tavoni, Robbie M. Andrew, Philippe Ciais, et al. 2014. "Betting on Negative Emissions.” Nature Climate Change 4(10):850-53.

Galgani, Pietro, Ester van der Voet, and Gijsbert Korevaar. 2014. “Composting, Anaerobic Digestion and Biochar Production in Ghana: Environmental-economic Assessment in the Context of Voluntary Carbon Markets.” Waste Management 34(12):2454-65.

Harnisch, Sebastian, Stephanie Uther, and Miranda Boettcher. 2015. “From 'go Slow' to 'gung Ho’? Climate Engineering Discourses in the UK, the US, and Germany.” Global Environmental Politics 15(2):57-78.

Haro, Pedro, Cristina Aracil, Fernando Vidal-Barrero, and Pedro Ollero. 2015. "Rewarding of ExtraAvoided GHG Emissions in Thermochemical Biorefineries Incorporating Bio-CCS.” Applied Energy 157:255-66.

Harvey, David. 1999. The Limits to Capital. London: Verso.

Heck, Vera, Dieter Gerten, Wolfgang Lucht, and Lena R. Boysen. 2015. "Is Extensive Terrestrial Carbon Dioxide Removal a 'green’ Form of Geoengineering? A Global Modelling Study.” Global and Planetary Change Forthcoming.

Hulme, Mike. 2014. Can Science Fix Climate Change: A Case against Climate Engineering. Cambridge: Polity Press.

Isla, Ana. 2015. The “greening” of Costa Rica: Women, Peasants, Indigenous People, and the Remaking of Nature. Toronto: University of Toronto Press.

Keith, David. 2013. A Case for Climate Engineering. Boston: MIT Press.

Keith, David W. and Douglas G. MacMartin. 2015. “A Temporary, Moderate and Responsive Scenario for Solar Geoengineering.” Nature Climate Change 5(3):201-6.

Keith, David W., Edward A. Parson, and M.Granger Morgan. 2010. "Research on Global Sun Block Needed Now.” Nature 463:426-27.

Klein, Naomi. 2014. This Changes Everything: Capitalism vs. the Climate. Alfred A. Knopf Canada.

Lockley, Andrew. 2016. "Licence to Chill: Building a Legitimate Authorisation Process for Commercial SRM Operations.” Environmental Law Review 18(1):25-40.

Lohmann, Larry. 2006. Carbon Trading: A Critical Conversation on Climate Change, Privatisation and Power. Uppsala (Sweden): The Dag Hammarskjöld Centre.

Lohmann, Larry. 2008. “Carbon Trading, Climate Justice and the Production of Ignorance: Ten Examples.” Development 51(3):359-65.

Lohmann, Larry. 2014. "Performative Equations and Neoliberal Commodification: The Case of Climate.” Pp. 158-80 in Nature ${ }^{T M}$ Inc: environmental conservation in the neoliberal age, edited by Robert Fletcher, Wolfram Dressler, and Bram Büscher. Tucson: University of Arizona Press.

Longo, Stefano B., Rebecca Clausen, and Brett Clark. 2015. The Tragedy of the Commodity: Oceans, Fisheries, and Aquaculture. New Brunswick (NJ): Rutgers University Press.

Luke, Timothy W. 2010. “Geoengineering as Global Climate Change Policy.” Critical Policy Studies 4(2):111-26.

Macnaghten, Phil and Bronislaw Szerszynski. 2013. "Living the Global Social Experiment: An 
Analysis of Public Discourse on Solar Radiation Management and Its Implications for Governance.” Global Environmental Change 23(2):465-74.

Magdoff, Fred and John Bellamy Foster. 2011. What Every Environmentalist Needs to Know about Capitalism: A Citizen's Guide to Capitalism and the Environment. NYU Press.

Malm, Andreas. 2015. “Socialism or Barbeque, War Communism or Geo-Engineering: Some Thoughts on Choices in a Time of Emergency.” Pp. 180-94 in The politics of ecosocialism: Transforming welfare, edited by Kajsa Borgnäs, Teppo Eskelinen, Johanna Perkiö, and Rikard Warlenius. London: Routledge.

Marshall, Michael. 2011. "Political Backlash to Geoengineering Begins.” New Scientist.

Michaelson, Jay. 1998. “Geoengineering: A Climate Change Manhattan Project.” Stanford Environmental Law Journal 17(73):74-140.

Morgan, Jamie. 2016. “Paris COP 21: Power That Speaks the Truth?” Globalizations Forthcoming.

National Research Council. 2015a. Climate Intervention: Carbon Dioxide Removal and Reliable Sequestration. Washington, D.C.: National Academy of Science.

National Research Council. 2015b. Climate Intervention: Reflecting Sunlight to Cool Earth. Washington, D.C.: National Academy of Science.

Newell, Peter and Matthew Paterson. 2010. Climate Capitalism: Global Warming and the Transformation of the Global Economy. Cambridge: Cambridge University Press.

Parson, Edward A. 2014. “Climate Engineering in Global Climate Governance: Implications for Participation and Linkage.” Transnational Environmental Law 3(1):89-110.

Parson, Edward A. and Lia N. Ernst. 2015. “Climate Engineering: New Challenges for Scientific Assessment and Global Governance.” Pp. 126-40 in A subtle balance: Expertise, evidence, and democracy in public policy and governance, 1970-2010, edited by Edward A. Parson. Montreal and Kingston: McGill-Queen’s University Press.

Paterson, Matthew, Matthew Hoffmann, Michele Betsill, and Steven Bernstein. 2014. “The Micro Foudations of Policy Diffusion toward Complex Global Governance: An Analysis of the Transnational Carbon Emission Trading Network.” Comparative Political Studies 47(3):42049.

Rickels, Wilfried, Gernot Klepper, Jonas Dovern, Gregor Betz, Nadine Brachatzek, Sebastian Cacean, et al. 2011. Large-Scale Intentional Interventions into the Climate System? Assessing the Climate Engineering Debate. Scoping Report Conducted on Behalf of the German Federal Ministry of Education and Research. Kiel: Kiel Earth Institute.

Rickels, Wilfried, Katrin Rehdanz, and Andreas Oschlies. 2012. "Economic Prospects of Ocean Iron Fertilization in an International Carbon Market.” Resource and Energy Economics 34(1):12950.

Robock, Alan. 2008. “20 Reasons Why Geoengineering May Be a Bad Idea.” Bulletin of the Atomic Scientists 64(2):14-18.

Robock, Alan. 2012. “Will Geoengineering with Solar Radiation Management Ever Be Used?” Ethics, Policy \& Environment 15(2):202-5.

Rockström, Johan, Will Steffen, Kevin Noone, Åsa Persson, F.Stuart III Chapin, Eric F. Lambin, et al. 2009. “A Safe Operating Space for Humanity.” Nature 461:472-75.

Salleh, Ariel. 2012. “Green Economy or Green Utopia? Rio+20 and the Reproductive Labor Class.” 
Journal of World-Systems Research 18(2):141-45.

Sapinski, Jean Philippe. 2015. “Climate Capitalism and the Global Corporate Elite Network.” Environmental Sociology 1(4):268-79.

Sapinski, Jean Philippe. 2016. "Constructing Climate Capitalism: Corporate Power and the Global Climate Policy-planning Network.” Global Networks 16(1):89-111.

Sargoni, Janine and Andrew Lockley. 2015. "Environment Policy: Solar Radiation Management and the Voluntary Carbon Market.” Environmental Law Review 17(4):266-69.

Schneider, Stephen H. 1996. “Geoengineering: Could— or Should— We Do It?” Climatic Change 33(3):291-302.

Schneider, Stephen H. 2001. “Earth Systems Engineering and Management.” Nature 409(6818):41721.

Scholte, Samantha, Eleftheria Vasileiadou, and Arthur C. Petersen. 2013. "Opening up the Societal Debate on Climate Engineering: How Newspaper Frames Are Changing.” Journal of Integrative Environmental Sciences 10(1):1-16.

Schultz, Jessica and Richard York. 2011. "Recognizing Overshoot: Succession of an Ecological Framework.” Human Ecology Review 18(2):139-46.

Shiermeier, Quirin. 2009. “Ocean Fertilization Experiment Draws Fire.” NatureNews, January 9.

Sillmann, Jana, Timothy M. Lenton, Anders Levermann, Konrad Ott, Mike Hulme, François Benduhn, et al. 2015. “Climate Emergencies Do Not Justify Engineering the Climate.” Nature Climate Change 5(4):290-92.

Smith, Neil. 2007. “Nature as Accumulation Strategy.” Socialist Register 43.

Smith, Nicola J., Garry W. McDonald, and Murray G. Patterson. 2014. "Is There Overshoot of Planetary Limits? New Indicators of Human Appropriation of the Global Biogeochemical Cycles Relative to Their Regenerative Capacity Based on ‘ecotime’ Analysis.” Ecological Economics 104:80-92.

Smith, Pete, Steven J. Davis, Felix Creutzig, Sabine Fuss, Jan Minx, Benoit Gabrielle, et al. 2016. “Biophysical and Economic Limits to Negative CO2 Emissions.” Nature Climate Change 6:4250.

Spash, Clive L. 2016. “This Changes Nothing: The Paris Agreement to Ignore Reality.” Globalizations Forthcoming.

Strong, Aaron, Sallie Chisholm, Charles Miller, and John Cullen. 2009. “Ocean Fertilization: Time to Move on.” Nature 461(7262):347-48.

Surprise, Kevin. 2015. "Planetary Politics: The Anthropocene, Geoengineering, and the Subsumption of the Biosphere.” Under review.

The Royal Society. 2009. Geoengineering the Climate: Science, Governance and Uncertainty. London: The Royal Society.

Vlachou, Andriana. 2014. “The European Union’s Emissions Trading System.” Cambridge Journal of Economics 38(1):127-52. 